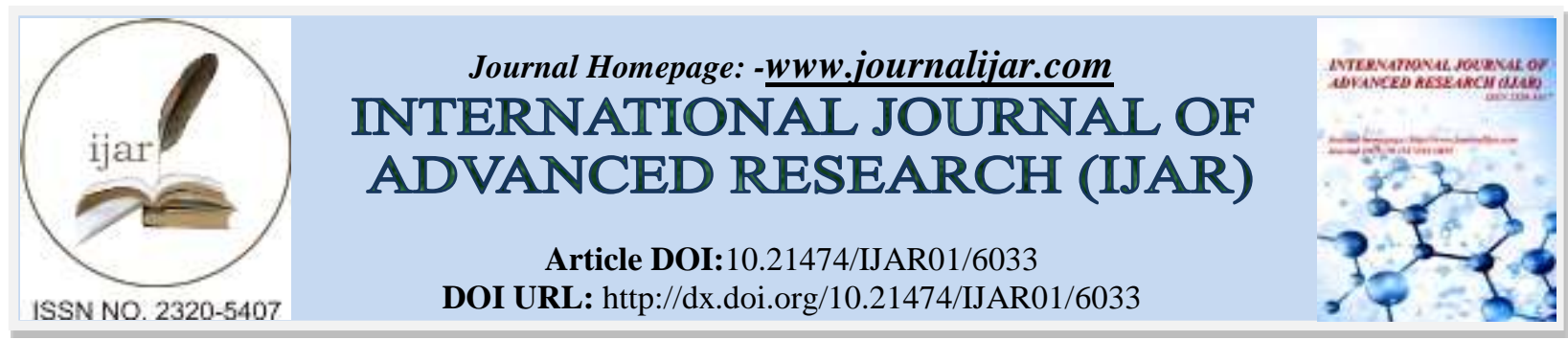

RESEARCH ARTICLE

\title{
ISOLATION, SCREENING AND CHARACTERIZATION OF HEAVY METAL RESISTANCE BACTERIA FOR THEIR POTENTIAL USE IN BIOREMEDIATION OF POLLUTED WATER.
}

Snehal Kale ${ }^{1}$, Narsingrao Bandela ${ }^{1}$ and ${ }^{*}$ Sayaji Mehetre ${ }^{2}$.

1. Dept of Environmental Science, Dr Babasaheb Ambedkar Marathwada University, Aurangabad.

2. Nuclear Agriculture and Biotechnology Division, Bhabha Atomic Research Centre, Mumbai.

\section{Manuscript Info}

Manuscript History

Received: 12 October 2017

Final Accepted: 14 November 2017

Published: December 2017

Key words:-

CETP, Bioremediation, Metal resistance microorganisms.

\begin{abstract}
Native species of microorganism provides a potential system for the treatment of metal contaminated water. Present study was conducted to screen and characterize heavy metal resistance bacteria in order to remediate the effluent waste water. Nine strains were isolated and designated as WAs1, WCd2, WCo3, WCr4, WCu5, WHg6, WNi7, WPb8 \& WZn9 based on their maximum threshold level of tolerance to each metal. These values for respective metal are Arsenic (1000 ppm), Cadmium (200 ppm), Cobalt (400 ppm), Chromium (20 ppm), Copper $(100 \mathrm{ppm})$, Mercury (20 ppm), Nickel (50 ppm), Lead (1000 ppm) and Zinc (1000 ppm). The highest values with respect to arsenic and lead observed during this study are not reported so far showing the importance of the work. Maximum growth of these strains was observed at $\mathrm{pH} 7$ and $37^{\circ} \mathrm{C}$ temperature. These strains were further characterized by biochemical and morphological methods.
\end{abstract}

Copy Right, IJAR, 2017,. All rights reserved.

\section{Introduction:-}

Environmental contamination by heavy metals from anthropogenic and industrial activities has caused considerable irreparable damage to aquatic ecosystems. Industrial wastes containing toxic metals can arise from a wide variety of industrial processes (Mohammed and Normala 2015). According to the World Health Organization (WHO), metals of most immediate concern include cadmium, chromium, cobalt, copper, lead, nickel, mercury and zinc. These metals have exacting consequences on human such as brain damage, reproductive failure, nervous system failure and tumor formation (Gleick 2014). Industrial effluent is usually collected at a common place for its treatment. Waste water from Common Effluent Treatment Plant (CETP), Navi Mumbai industrial area was characterized and used to make it suitable for land applications. For this purpose different bacteria tolerant to heavy metal were isolated and were screened for their ability to decontaminate the effluent. This effluent was characterized by high BOD, COD and higher levels of TDS making it unsuitable for flora and fauna of the ecosystem.

Bioremediation, which is essentially the use of microbial metabolism, seems to offer a viable, safer, more efficient and less expensive alternative to physiochemical methods for pollution abatement (Pandey and Jain, 2002).

Considering this aspects bacterial strains were isolated and characterized for their growth parameters in order to make their effective utilization for decontamination of polluted water and making it suitable for cultivation. 


\section{Material and Method:- \\ Collection of sample:}

The effluent water samples were collected from Common Effluent Treatment Plant (CETP), Navi Mumbai. The samples (in duplicate) were collected in a sterile plastic container (5 liter capacity) which was sealed subsequently with paraffin and brought in the laboratory.

\section{Isolation of heavy metal resistance bacteria:}

For isolation and purification, $1 \mathrm{ml}$ of effluent water was inoculated in nutrient broth medium (Himedia, India) and incubated at $37^{\circ} \mathrm{C}$. The stock solution of different metals salts was prepared as Arsenic Sulfate $\left(\mathrm{AsSO}_{4}\right), \mathrm{Cadmium}$ Chloride $\left(\mathrm{CdCl}_{2}\right)$, Chromium $\left(\mathrm{K}_{2} \mathrm{Cr}_{2} \mathrm{O}_{7}\right)$, Cobalt Sulfate $\left(\mathrm{CoSO}_{4}\right)$, Copper Sulfate $\left(\mathrm{CuSO}_{4}\right)$, Lead Sulfate $\left(\mathrm{PbSO}_{4}\right)$, Mercury Sulfate $\left(\mathrm{HgSO}_{4}\right)$, Nickel chloride $\left(\mathrm{NiCl}_{2}\right)$ and Zinc Sulfate $\left(\mathrm{ZnSO}_{4}\right)$ in distilled water. Subsequently desired metal concentration was added in a petri plates containing Nutrient agar medium (Himedia, India) and incubated at $37^{\circ} \mathrm{C}$ (Joshi and Modi 2013). After complete growth single colony was isolated and transferred to another plate containing the respective metal.

\section{Determine threshold level of metal resistance:}

To determine maximum tolerance concentration (MIC) of heavy metal salts such as Arsenic Sulfate $\left(\mathrm{AsSO}_{4}\right)$, Cadmium Chloride $\left(\mathrm{CdCl}_{2}\right)$, Chromium $\left(\mathrm{K}_{2} \mathrm{Cr}_{2} \mathrm{O}_{7}\right)$, Cobalt Sulfate $\left(\mathrm{CoSO}_{4}\right)$ Copper Sulfate $\left(\mathrm{CuSO}_{4}\right)$, Lead Sulfate $\left(\mathrm{PbSO}_{4}\right)$ Mercuric Sulfate $\left(\mathrm{HgSO}_{4}\right)$, Nickel Chloride $\left(\mathrm{NiCl}_{2}\right)$, Zinc Sulfate $\left(\mathrm{ZnSO}_{4}\right)$ in nutrient agar plates with gradually increase concentration of respective heavy metal (Ansari et al. 2016). The initial minimum concentration used was $50 \mathrm{ppm}$ and it was subsequently transferred to NA agar plates with higher concentration till the growth of the bacteria in the plate.(Tendulkar 2016)

\section{Characterization of bacteria.}

All the strains were characterized for the growth parameters mentioned as follows.

\section{Optimum pH:}

The optimal growth conditions with reference to $\mathrm{pH}$ was determined by growing the strains in Nutrient broth with different $\mathrm{pH}$ (viz. 4, 6, 7, 9, 10, 11) and incubated at $37^{\circ} \mathrm{C}$ for $24 \mathrm{hr}$. Growth was quantified in terms of OD measured by UV-Spectrophotometer (Model V 530, Jasco, Japan) at $600 \mathrm{~nm}$.

\section{Optimum temperature:}

The optimal growth conditions with reference to temperature were studied by growing each strain in a Nutrient medium and incubated at $25^{\circ} \mathrm{C}, 30^{\circ} \mathrm{C}, 35^{\circ} \mathrm{C}, 37^{\circ} \mathrm{C}, 40^{\circ} \mathrm{C}$ for $24 \mathrm{hr}$. Growth was quantified in terms of OD measured as mentioned earlier.

\section{Salt tolerance:}

Test tubes containing nutrient broth medium with different concentration of sodium chloride (1 to $10 \%$ ) were inoculated with each strain and incubated at $37^{\circ} \mathrm{C}$ for $24 \mathrm{hr}$ and the growth was measured as mentioned earlier (Zhang 2008).

\section{Enzyme potential of bacteria:- \\ Starch Hydrolysis:}

Potato starch $(10 \%)$ was added to nutrient agar medium and inoculated with all the cultures and incubated at $37^{\circ} \mathrm{C}$. At 3 and 5 days, the plates were flooded with $95 \%$ ethanol. After 15 to 30 min, the unchanged starch became white and opaque (Pascale et al. 2005). Observations were made for a clear zone underneath and around the growth indicating the hydrolysis.

\section{Casein Decomposition:}

Milk agar plates was inoculated with cultures and incubated at $37^{\circ} \mathrm{C}$ for $2-3$ days. Clear zone around the growth indicating casein hydrolysis. (Dong 2000) 


\section{Cellulose:}

Medium containing $1 \%$ cellulose was inoculated with with culture and incubated at $37^{\circ} \mathrm{C}$ for 2 days the plates were flooded by iodine to detect the zone of clearance due to cellulose production. (Coleman et.al. 2009)

\section{Carbon assimilation capacity of bacteria:}

The ability of the isolates to utilize different carbon substrate was tested by adding different carbon sources (Lactose, Dextrose, Sorbitol, Mannitol, Arabinose, and xylose) in minimal medium at $1 \%$ concentration. Individual strains were streaked on the plates and incubated at $37^{\circ} \mathrm{C}$ for $24 \mathrm{hr}$.(Denef et al. 2009)

\section{Study of growth of bacteria:}

Each isolate was studied for its growth pattern after inoculating overnight grown culture and incubating at $37^{\circ} \mathrm{C}$. Aliquots of samples were drawn at every $2 \mathrm{hr}$ interval and growth were measured as optimal density (OD) using UV - spectrophotometer (Model V 530, Jasco, Japan) @ 600 nm.

\section{Morphological and biochemical study:}

Bacterial strains were morphologically identified using Gram staining (Gram, 1884) and characterized morphologically as per standard protocol mentioned in Bergey's manual. (David HandricksBergey 1923). Shape (form), size, elevation color, opacity were studied. and other biochemical tests which include; indole production,methyl red vogus proskauer ( MR- VP), citrate utilization,catalase, oxidase.(Wingender et al. 2001)

\section{Bioremediation of effluent waste water using isolated strains.}

All the selected strains were gown in nutrient broth and incubated at $37^{\circ} \mathrm{C}$ for $24 \mathrm{hr}$ and centrifuged @ $10000 \mathrm{rpm}$ to get the desired pellet and $0.1 \%$ (w/v) inoculum was used per $100 \mathrm{ml}$ of waste water (Garecha et al 2016). The flasks were incubated for 3 to 4 days at room temperature with a control flask without culture .Observation like change in colour, $\mathrm{pH}$, and COD reduction were done at the end of incubation (Bayoumi et al. 2014).

\section{Result and Discussion:-}

Isolation and selection of heavy metal resistance bacteria:

Based on the maximum threshold limit 9 strains were isolated on the basis of colony characterization and growth behavior and designated as WAs1, WCd2, WCr3, WCo4, WCu5, WPb6, WHg7, WNi8, WZn9. It was found that Arsenic, lead and Zinc tolerance was observed up to $1000 \mathrm{ppm}$ to the respective strains and WCr4, WHg6 isolate showed tolerance below 50ppm for Chromium and Mercury. The maximum threshold limits for respective strain are shown in Table. 1

\begin{tabular}{|l|l|l|l|}
\hline No & Bacterial strain & Tested metal & MTC $(\mathrm{ppm})$ \\
\hline 1 & WAs1 & Arsenic & 1000 \\
\hline 2 & WCd2 & Cadmium & 200 \\
\hline 3 & WCo3 & Cobalt & 400 \\
\hline 4 & WCr4 & Chromium & 20 \\
\hline 5 & WCu5 & Copper & 100 \\
\hline 6 & WHg6 & Mercury & 20 \\
\hline 7 & WNi7 & Nickel & 50 \\
\hline 8 & WPb8 & Lead & 1000 \\
\hline 9 & WZn9 & Zinc & 1000 \\
\hline
\end{tabular}

Table 1:- Heavy metal resistant bacterial strains and their MTC.

\section{Optimization of growth parameters:-}

pH

Each strain was studied for its optimum $\mathrm{pH}$ requirement based on maximum OD observed for each strain. It was found that strain WAs1 showed optimum pH at 11 and all other strains showed optimum grow at pH 7 (Fig. 1). 


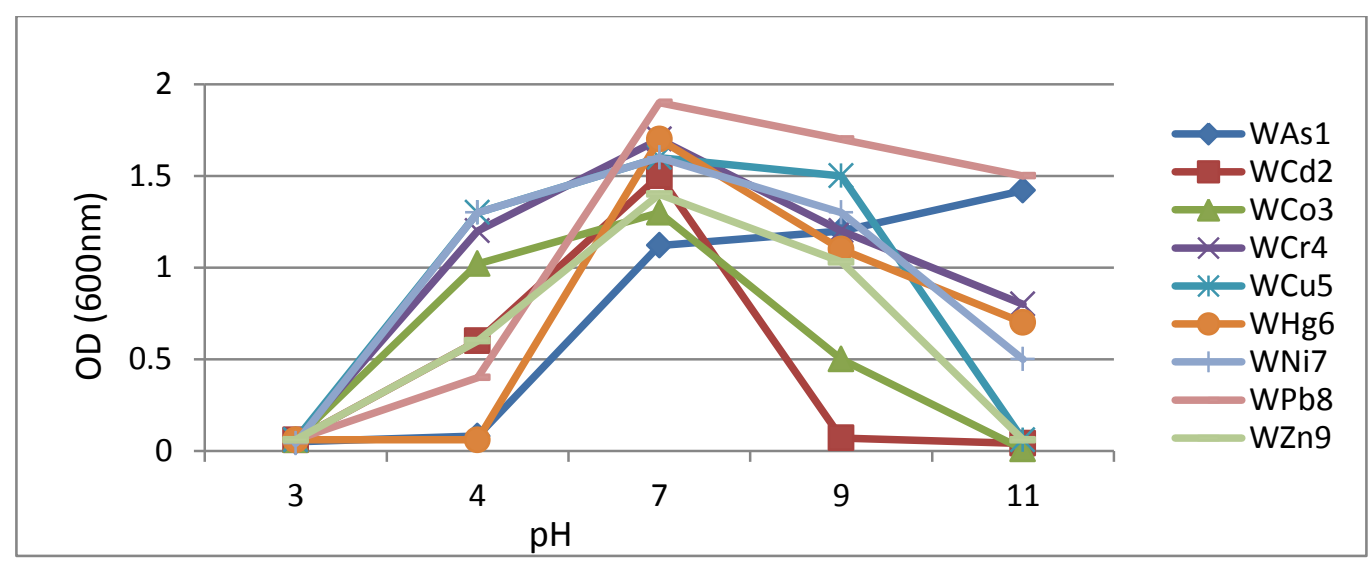

Fig 1:- pH requirement of different strains

\section{Temperature:-}

Based on the maximum growth observed by the bacteria it was found that all the strains grew at $37^{0} \mathrm{C}$ temperature (Fig. 2).

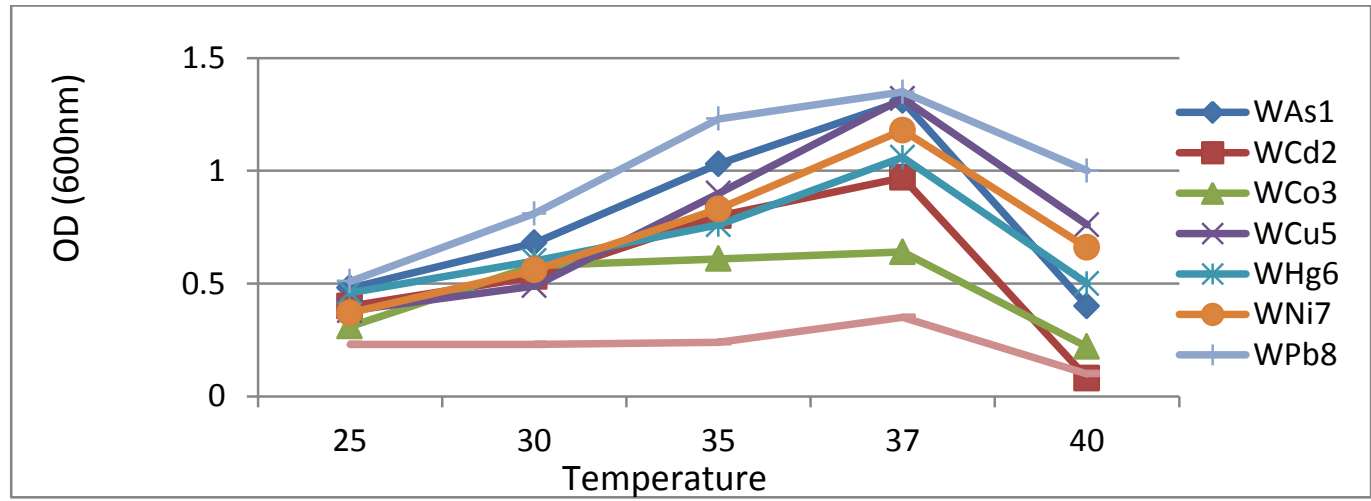

Fig 2:- Temperature requirement of different strains

\section{Salt tolerance:}

All bacterial isolates show salt tolerance for $1 \%, 2 \%, 3 \%, 4 \%, 5 \%, 6 \%, 7 \%, 8 \%, 9 \%, 10 \%$ salt concentration. All bacterial isolates show tolerance to all salt concentration but growth was decreasing from $1 \%$ to $10 \%$ salt concentration.

\section{Enzyme potential of bacteria:}

The details of the enzyme activity of isolated strains are given in Table 2. Strain resistant to cadmium (WCd2) was found to be cellulose positive and lead resistant strain (WPb8) was citrate positive and other strain showed mixed response among the studied enzymes (Sidkey et al. 2010).

\begin{tabular}{|l|l|l|l|l|}
\hline \multirow{2}{*}{ Isolates } & \multicolumn{3}{|c|}{ Enzymes potential of bacteria } \\
\cline { 2 - 5 } & Starch hydrolysis & Casein decomposition & $\begin{array}{l}\text { Citrate } \\
\text { utilization }\end{array}$ & $\begin{array}{l}\text { Cellulose } \\
\text { production }\end{array}$ \\
\hline WAs1 & ++ & - & ++ & - \\
\hline WCd2 & - & - & - & + \\
\hline WCo3 & ++ & - & ++ & - \\
\hline WCr4 & ++ & - & ++ & ++ \\
\hline WCu5 & ++ & - & ++ & ++ \\
\hline WHg6 & ++ & ++ & ++ & ++ \\
\hline WNi7 & ++ & - & ++ & + \\
\hline WPb8 & - & - & ++ & - \\
\hline
\end{tabular}




\begin{tabular}{|l|l|l|l|l|}
\hline WZn9 & ++ & - & - & ++ \\
\hline
\end{tabular}
++ Higher activity, + less activity, - No activity. Table 2: Enzyme activity

Carbon assimilation capacity of bacteria:-

The ability of strains to utilize different carbon source has been depicted in Table 3. It was found that there was no uniformity with respect to the utilization of sugars and strains utilized variety of sugars for their growth.

\begin{tabular}{|c|c|c|c|c|c|c|c|c|c|}
\hline \multirow[b]{2}{*}{$\begin{array}{l}\text { Carbon } \\
\text { source }\end{array}$} & \multicolumn{9}{|c|}{ Bacterial strains } \\
\hline & WAs1 & $\mathrm{WCd} 2$ & WCo3 & WCr4 & WCu5 & WHg6 & WNi7 & WPb8 & WZn9 \\
\hline Arabinose & + & - & + & + & + & + & + & + & + \\
\hline Dextrose & - & + & - & + & + & + & + & + & - \\
\hline Glucose & + & + & + & + & + & + & + & + & + \\
\hline Lactose & - & - & + & + & + & - & + & - & + \\
\hline Mannitol & + & - & + & + & + & + & - & - & + \\
\hline Sorbitol & - & - & + & + & + & - & + & + & - \\
\hline Xylose & + & - & - & + & + & + & + & + & - \\
\hline
\end{tabular}

$+=$ positive result, $-=$ negative result . Table 3: Carbon source utilization by the bacterial isolates.

\section{Growth Curve.}

Growth curve of all 9 strains was studied in order to understand the growing nature of the isolates to get the maximum growth in minimum time. Growth curve of each isolates are given in Fig 4.

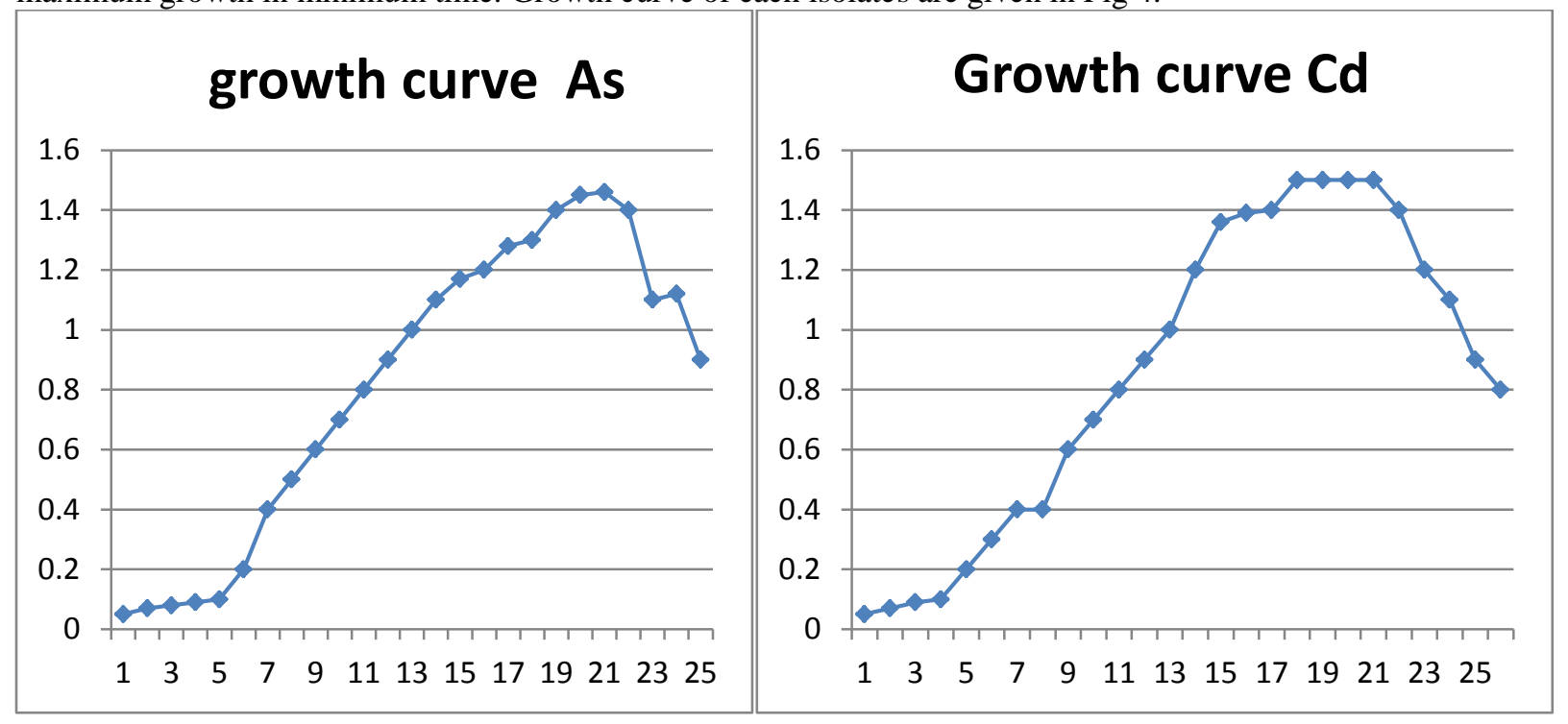




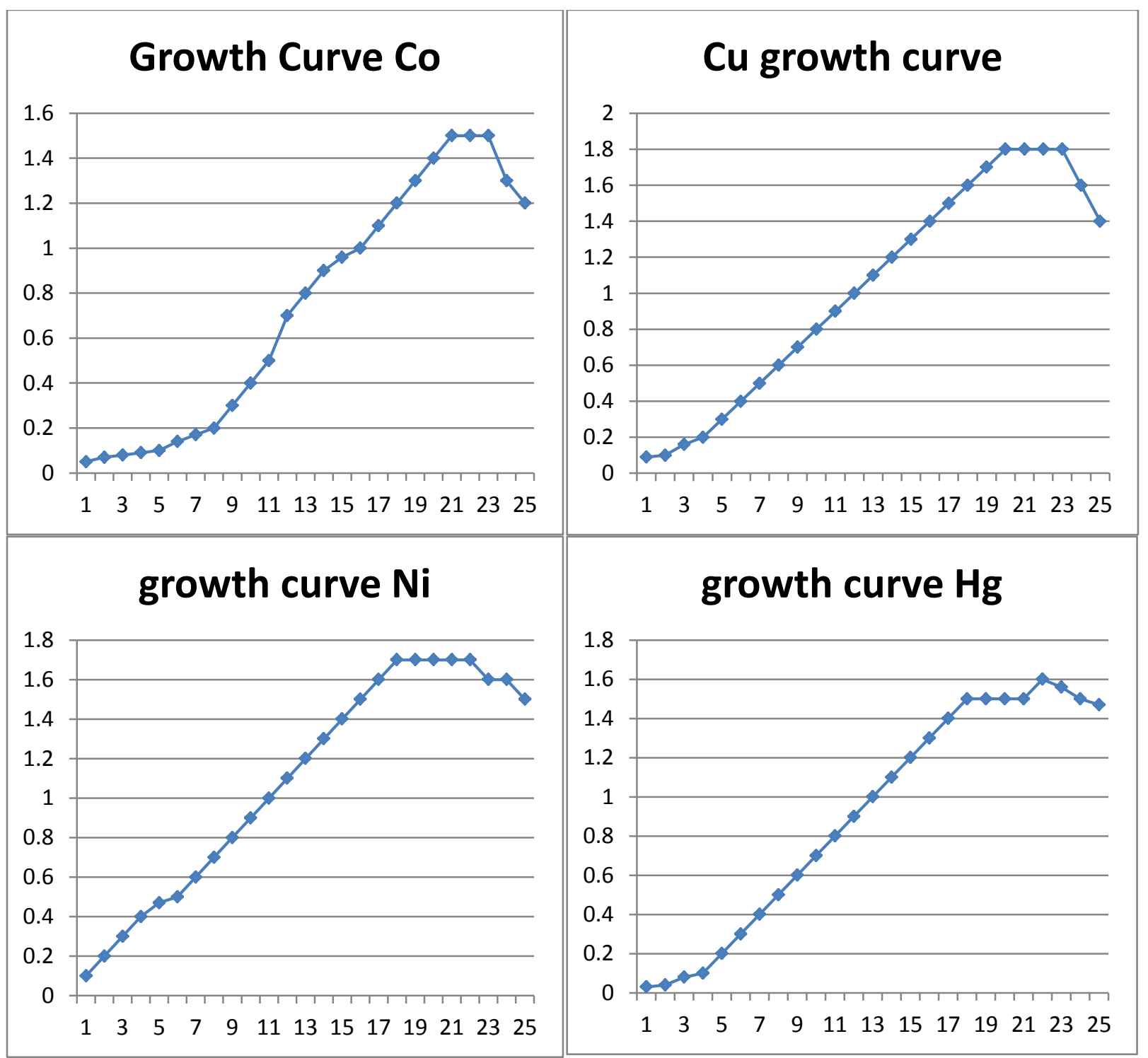



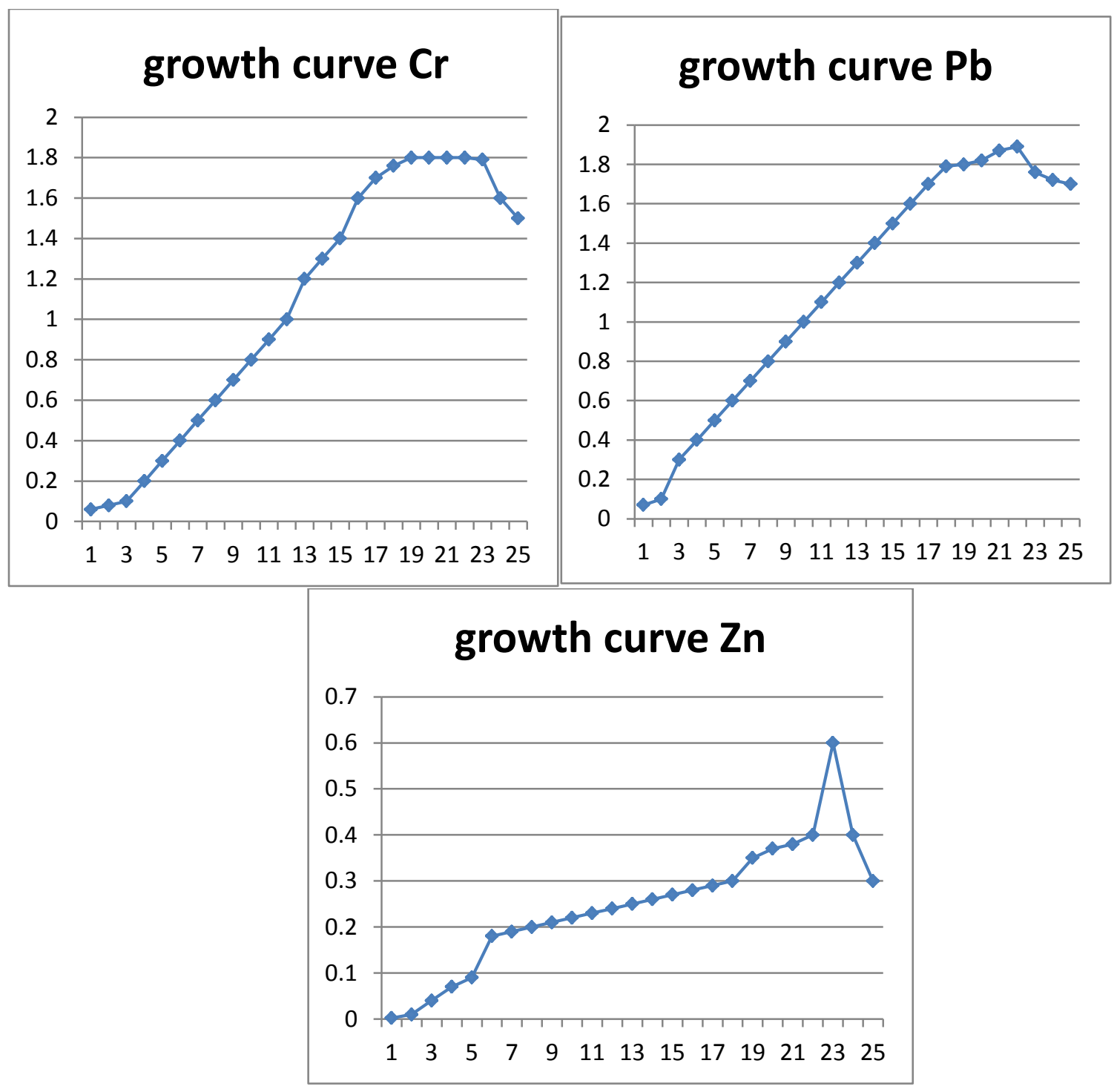

Morphological and biochemical study:-

Bacterial strains were characterized on the basis of Gram nature and shape. It was found that the strains WAs1, WCd2, WCo3, WCr4, WCu5, WHg6, WNi7 and WPb8 were gram negative and strain WZn9 was gram positive in nature. Strains WAs1, WCd2, WCo3, WCr4, WCu5, WHg5 and WZn9 were cocci in shape and strain WNi7 and WPb8 were rod shape. Colony characteristics of each strain are given in Table 4.

\begin{tabular}{|l|l|l|l|l|l|l|}
\hline \multirow{2}{*}{ Isolates } & Colony Characteristic \\
\cline { 2 - 7 } & Form & Elevation & Margin & Colour & Size cm & Opacity \\
\hline WAs1 & Circular & Raised & Entire & Light brown & 0.3 & Translucent \\
\hline WCd2 & Irregular & Flat & Undulate & white & 0.4 & Opaque \\
\hline WCo3 & Irregular & Flat & Undulate & white & 0.3 & Translucent \\
\hline WCr4 & Circular & Convex & Entire & white & 0.4 & Opaque \\
\hline WCu5 & Circular & Raised & Entire & white & 0.4 & Translucent \\
\hline WHg6 & Circular & Flat & Entire & white & 0.25 & Opaque \\
\hline WNi7 & Irregular & Flat & Entire & white & 0.3 & Opaque \\
\hline WPb8 & Irregular & Flat & Undulate & Light brown & 0.3 & Translucent \\
\hline WZn9 & Round & Flat & Entire & white & 0.1 & Translucent \\
\hline
\end{tabular}

Table 4:-Morphological studies of bacterial isolate. 
For biochemical characterization, the details are given in Table 5.

\begin{tabular}{|c|c|c|c|c|c|c|c|c|c|}
\hline \multirow[t]{2}{*}{ Biochemical test } & \multicolumn{9}{|c|}{ Bacterial strains } \\
\hline & WAs1 & $\mathrm{WCd} 2$ & WCo3 & WCr4 & WCu5 & WHg6 & WNi7 & WPb8 & WZn9 \\
\hline Indole production & - & + & + & + & + & - & + & + & + \\
\hline Methyl Red test & + & + & + & + & + & + & + & + & + \\
\hline Voges-Proskauer & - & - & - & - & - & - & - & - & - \\
\hline Citrate utilization & + & - & + & + & + & + & + & + & - \\
\hline Catalase & + & + & + & + & + & + & + & + & + \\
\hline Oxidase & + & - & - & - & - & + & - & + & - \\
\hline
\end{tabular}

$+=$ positive,$-=$ negative. Table 5 . Biochemical Studies of bacterial isolate.

\section{Bioremediation of waste water using isolates:}

All the isolated strains were examined for their ability to treat the waste in terms of COD reduction and color. It was found that strain WCr7 reduced the COD by $90 \%$ in $4-5$ days (Table 6). This helped in screening these strains for further utilization in bioremediation purpose ( $\mathrm{Gad}$ et al. 2010)

\begin{tabular}{|l|l|c|c|c|}
\hline No & Bacterial strain & PH & Color (\%) & \% COD reduction \\
\hline 1 & WAs1 & 7 & 30 & 15 \\
\hline 2 & WCd2 & 7 & 40 & 72 \\
\hline 3 & WCo3 & 7 & 35 & 90 \\
\hline 4 & WCr4 & 7 & 28 & 80 \\
\hline 5 & WCu5 & 7 & 60 & 80 \\
\hline 6 & WHg6 & 7 & 80 & 58 \\
\hline 7 & WNi7 & 7 & 70 & 70 \\
\hline 8 & WPb8 & 7 & 10 & 71 \\
\hline 9 & WZn9 & 7 & 15 & \\
\hline
\end{tabular}

Table 6:- COD reduction of waste water.

\section{Conclusion:-}

Different bacterial strains were isolated from effluent water and used for their ability to reduce the COD being major parameter of water quality. It was observed that there was 80-90\% COD reduction by these isolates. These isolates were also tested for their resistance to heavy metals based on the maximum threshold limits. Strains WAs1, WCd2, WCo3, WCr4, WCu5, WHg6, WNi7, WPb8 and WZn9 showed tolerance to Arsenic (1000 ppm), Cadmium (200 ppm), Cobalt (400 ppm) Chromium (20 ppm), Copper (100 ppm) Mercury (20 ppm), Nickel (50 ppm), lead (1000 ppm) and Zinc (1000 ppm). Morphological, biochemical and molecular characterization of all these strains was completed. This study revealed the potential of heavy metal resistant isolates for bioremediation of waste water for its application to different purpose.

\section{References:-}

1. Gad. "Heavy metal Bio-remediation By Immobilized Saccharomyces Cervisiae and Opuntiaficusindica Waste". Journal of American Science, (2010). 6(8) 143 -158.

2. Ansari R. A, Qureshi A. A, Ramteke D.S "Isoaltion and characterization of heavy metal resistance microbes from Industrial Soil” International Journal of Environmental Science (2016).6,(5).100-110

3. David Handricks Bergey, John G. Holt “ Bergey’s manual of systematic bacteriology ."(1923)

4. Edward C. Raja, Selvam G.C., Omine Kiyoshi. " Isolation identification and characterization of heavy metal resistance bacteria from sewage." Intenational joint symposium on Geodisaster prevention on Geoenvironment in Asia JS-Fukuka (2009).114-120

5. GarchS, Verma N, Brar S.K. "Isolation, Characterization and Identification of Sludge samples and evaluation of their biodegradability" Water Resources and Industry (2016) $16: 19-28$.

6. Gleick P.H. "Water Drought Climate Change and conflict in Syria" American Metrological Society.(2014) 6: $331-339$.

7. Hans Christian gram (1884) "Milestones in Microbiology" 1546-1940 (2 ed.). ASM Press. pp. 215-218. ISBN 1-55581-142-6. 
8. Joshi B.H, Modi K. G "Screening and characterization of heavy metal resistance bacteria for its prospects in bioremediation of contaminated soil."Journal of Environmental Research and Development(2013) 7: 15311537.

9. Bayoumi MN,Al-Wasify RS, Hamed SR "Bioremediation of Textile Wastewater Dyes using Bacterial Isolates"International Journal of Current Microbiology and Applied Sciences. (2014)3(12) 962-970.

10. Mohammed Umar Mustapha, NormalaHalimoon"Screening and isolation of heavy metal tolerant bacteria in industrial effluent" Procedia Environmental Sciences (2015) 30:33-37.

11. Nagwa Mahmoud Sidkey, MahaAbda Al- Rahman Abo-shadi, AbeerMohammd Al- Mutrafy,Fatmasefergy and Nouf Al- Reheily "Screening of Microorganisms Isoalted from some Enviro-Agro- Industrial Waste in Saudi Arabia for Amylase Production". Journal of American Science(2010. 6(10) : 926-939.

12. Pandey Gunjan, Jain Rakesh "Bacterial chemotaxis toward environmental pollutants: Role in Bioremediation" Applied Environmental Microbiology (2002) 68 (12):5789-5795.

13. Tendulkar A, Yan Yi Wei, Murali Krishnan V "Isolation, identification and characterization of potential bacteria from Malaysian water water showing resistance to cadmium, copper and iron" Journal of Scientific Research and Development (2016). 3 (5): 216-220,.

14. Pascale Talamond, Noirot Michel, Kochko Alexandre De. "The Mechanism of Action of $\alpha$-amylase from Lactobacillus Fermentum on Maltooligosaccharides.”Journal of Chromatography B (2005): 42-47.

15. Dong oingzhi and Hsieh You-Lo "Acrylonitrile graft copolymerization of casein proteins for enhanced solubility and thermal properties.” Journal of Applied Ploymer Science (2000) 77: 2543-2551.

16. Polen Tino, Schluesener Daniela, Poetsch Ansgar ,Bott Michael, Wendish Volkar F. "Characterization of citrate utilization in Corynebacterium glutamicum by transcriptome and proteome analysis." (2007) 273, 1 : $109-119$.

17. Coleman Heather D, Yan Jimmy and Mansfield Shawn D "Sucrose synthase affects carbon partitioning to increase cellulose production and altered cell wall ultrastructure." PNAS(2009) $106: 13118-13123$.

18. Denef Karolien, Roobroeck Dries, Wadu Manimel C.W. Mihiri, Lootens Peter ,Boeckx Pascal "Journal of Soil Biology and Biochemestry.(2009), 41: 144- 153.

19. Wingender Jost, Strathmann Martin, Rode Alexander, Leis Andrew, Flemming Hans-curt"Isolation and biochemical characterization of extracellular polymeric substances from Pseudomonas aeruginosa" Journal of Methods in Enzymology.(2001) 336: 302-314.

20. Zhang H,Kim MS, Sun Y "Soil Bacteria Confer Plant Salt Tolerance by Tissue-Specific Regulation of the Sodium Transporter HKT1” The American Phytopathological Society.(2008) 21:734-744. 